\title{
EXTRACTION AND PURIFICATION OF PHYTOSTEROLS MIXTURE FROM PALM FATTY ACID DISTILLATE (PFAD) USING MULTISTAGE EXTRACTION PROCESSES
}

\author{
NOR FAIZAH JALANI*; NOORSHAMSIANA ABDUL WAHAB*; WAN HASAMUDIN WAN HASSAN*; \\ KAMARUDIN HASSAN*; NAHRUL HAYAWIN ZAINAL* and MOHAMAD FAIZAL IBRAHIM**
}

\begin{abstract}
Phytosterols are among the bioactive compounds naturally present in vegetable oils and their by-products or derivatives. A phytosterol resource (PSR), solid by-product from the extraction of vitamin $E$ in palm fatty acid distillate (PFAD), contains 2\%-4\% (w/w) total sterols. Therefore, the extraction of phytosterols from the PSR in a mini-pilot scale involving multistage extraction processes was developed to recover the valuable minor component. The multistage extraction and purification processes comprised of solid-liquid extraction (SLE) with hexane at $35^{\circ} \mathrm{C}$ in $1 \mathrm{hr}$, saponification reaction at the reflux temperature of $80^{\circ} \mathrm{C}$ for $1 \mathrm{hr}$, liquidliquid extraction (LLE) with hexane and water, and crystallisation and vacuum filtration at $-5^{\circ} \mathrm{C}$ for 20 $h r$. On average, gas chromatographic (GC) analysis showed the phytosterols recovered from the extraction and purification process had more than $80 \%$ purity. The recovery of total sterols from the PSR was $84 \%$ composed of $\beta$-sitosterol (21\%-22\%), campesterol (13\%-20\%) and stigmasterol (59\%-64\%). This extraction process is technically feasible to extract and produce crude phytosterols from a PFAD by-product.
\end{abstract}

Keywords: palm fatty acid distillate (PFAD), phytosterols, multistage extraction, palm oil by-product.

Received: 26 November 2019; Accepted: 11 March 2020; Published online: 22 September 2020.

\section{INTRODUCTION}

Phytosterols (plant sterols) are one of the bioactive compounds that occur naturally in vegetable oils and their by-products or derivatives. Phytosterols can be found in olive oil, sunflower oil and pistachios. Several types of phytosterols have been identified and reported but only $\beta$-sitosterol, campesterol and

\footnotetext{
Malaysian Palm Oil Board,

6 Persiaran Institusi, Bandar Baru Bangi,

43000 Kajang, Selangor, Malaysia.

E-mail: norfaizah@mpob.gov.my

** Department of Bioprocess Technology,

Faculty of Biotechnology and Biomolecular Sciences,

Universiti Putra Malaysia,

43400 UPM Serdang, Selangor, Malaysia.
}

stigmasterol exist in significant amount in these resources (Moreau et al., 2018; Massimo et al., 2019). Other types of phytosterols such as brassicasterol, $\Delta^{5}$-avenasterol, $\Delta^{7}$-avenasterol, sitostanol, campstanol and $\Delta^{7}$-stigmasterol can also be found in small quantities (Fernandes and Cabral, 2007). Furthermore, Moreau et al. (2018) have determined other types of phytosterols, which are stanols and their conjugates in foods.

Consumption of phytosterols has been reported to be able to reduce cholesterol absorption and lowering total serum and low density lipoprotein (LDL) cholesterol levels in animals and humans (Jones et al., 1999; Tasan et al., 2006). Phytosterols also showed anti-cancer property toward breast, colon and prostate cancer cell lines (Awad and Fink, 
2000). These important beneficial characteristics rendered phytosterols to have wide applications in nutraceuticals and functional food industries. Therefore, phytosterols can be incorporated into various types of food for enrichment to provide enough phytosterols for daily intake of $2 \mathrm{~g}$ per day (Devaraj and Jialal, 2006). Examples of functional food products containing phytosterols are margarine, butter, cereals, milk and spreads products, which are enriched with plant-derived sterols and their esters (Kowalski, 2017).

Commercial phytosterols are extracted from soyabean oil, corn oil, rapeseed oil, sunflower oil as well as tall oil. In palm oil, sterols can be found as minor component; together with tocotrienols, tocopherols, carotene, coenzyme Q10 and squalene. The sterols content in crude palm oil (CPO) ranges from 250 to 730 ppm (Chandrasekaram, 2009). Phytosterols are also present in the by-products of palm oil mill and refinery such as palm pressed fibre oil (PPFO) and palm fatty acid distillate (PFAD) in various concentrations depending on the processes (Ab Gapor, 2010; Lau et al., 2008). In Malaysia, 53 palm oil refineries are in operation with a total annual refining capacity of 27.33 million tonnes and thus about $765000 \mathrm{t}$ of PFAD are also being generated from the refining process (Kushairi et al., 2018). On average, PFAD contains about $0.4 \%$ phytosterols (Ab Gapor, 2010) and thus, it is estimated that about $3000 \mathrm{t}$ of phytosterols are available to be extracted from the PFAD.

Extraction of phytosterols can be conducted using several methods and extraction technologies depending on the source of raw materials (Fernandes and Cabral, 2007). The common recovery processes of phytosterols from oil are multistage processes of esterification, saponification, molecular distillation, crystallisation and filtration (Choo et al., 2005). Sterols in raw materials are partially found in ester form. As such, pre-treatments involving chemical modification such as saponification and hydrolysis are required to convert a component in the substance into different properties to allow for easier separation. These processes will convert sterol esters into unsaponifiable free sterols and also convert fatty acids and their esters into soap matrix (Fernandes and Cabral, 2007). Selective adsorption and desorption method using styrenediviynlbenzene type adsorbent with various type of solvents type such as methanol, isopropanol and hexane is also applied to enrich the phytonutrient content in CPO and PPFO (Phoon et al., 2018). A greener technology such as supercritical fluid extraction (SFE) was introduced to extract oil enriched with phytonutrient from PPFO, olive oil deodouriser and PFAD (Akgun, 2011; Lau et al., 2008; Norhidayah et al., 2012; Sugihara et al., 2010). The SFE is able to simultaneously extract carotene, vitamin E, squalene and phytosterols from the oil, which are then collected as fractional products from SFE based on the temperature and pressure of the supercritical carbon dioxide set during the operation. Ng and Choo (2013) developed a method using flash chromatography to recover phytonutrients such as carotenes from palm oil. Aqueous enzymatic method has also been found to be able to increase phytonutrients content in PPFO (Noorshamsiana et al., 2017). All of these green systems are able to recover phytonutrients from the feedstock. However, phytosterols concentration recovered were low, below $2 \%$. Therefore, additional processes are required in order to obtain high purity of individual phytonutrients. Moreover, as compared to conventional processes, these new technologies incur high capital cost and need skilled manpower.

Previous studies mainly focused on phytosterols extraction directly from CPO and deodourised distillates. Hence, few oil palm by-products from palm oil mills and refinery have been collected and analysed for their phytosterols content. This includes a solid by-product of the commercial vitamin E extraction from PFAD that has huge amount of unrecovered phytosterols. Suitable extraction and purification processes have yet to be properly developed to recover the phytosterols from this particular resource. Therefore, the aim of this study is to extract and purify the phytosterols from the solid by-product in a mini-pilot scale multistage extraction process. The recovery of this valuable component from the by-product of oil palm processing will help the oil palm industry to generate additional income and subsequently sustain the palm oil industry in Malaysia.

\section{MATERIALS AND METHOD}

\section{Materials Preparation}

$\mathrm{CPO}, \mathrm{PPFO}$, sludge palm oil (SPO) and oil palm empty fruit bunch (OPEFB) residual oil are collected from various sampling points at several palm oil mills in Peninsular Malaysia. All samples were stored at $4^{\circ} \mathrm{C}$ prior to analysis. PFAD was purchased from an oil refinery company (MOI Foods Malaysia Sdn Bhd, Selangor, Malaysia) and stored in a stainless steel drum before the extraction processes.

PFAD was then subjected to several processes, consisting of esterification, transesterification, distillation, crystallisation and ion exchange adsorption as depicted in Figure 1, adapted from vitamin $\mathrm{E}$ extraction method by Ab Gapor et al. (1993). The solid by-product after the crystallisation process known as phytosterol resources (PSR) was collected and analysed for its phytonutrients content. 


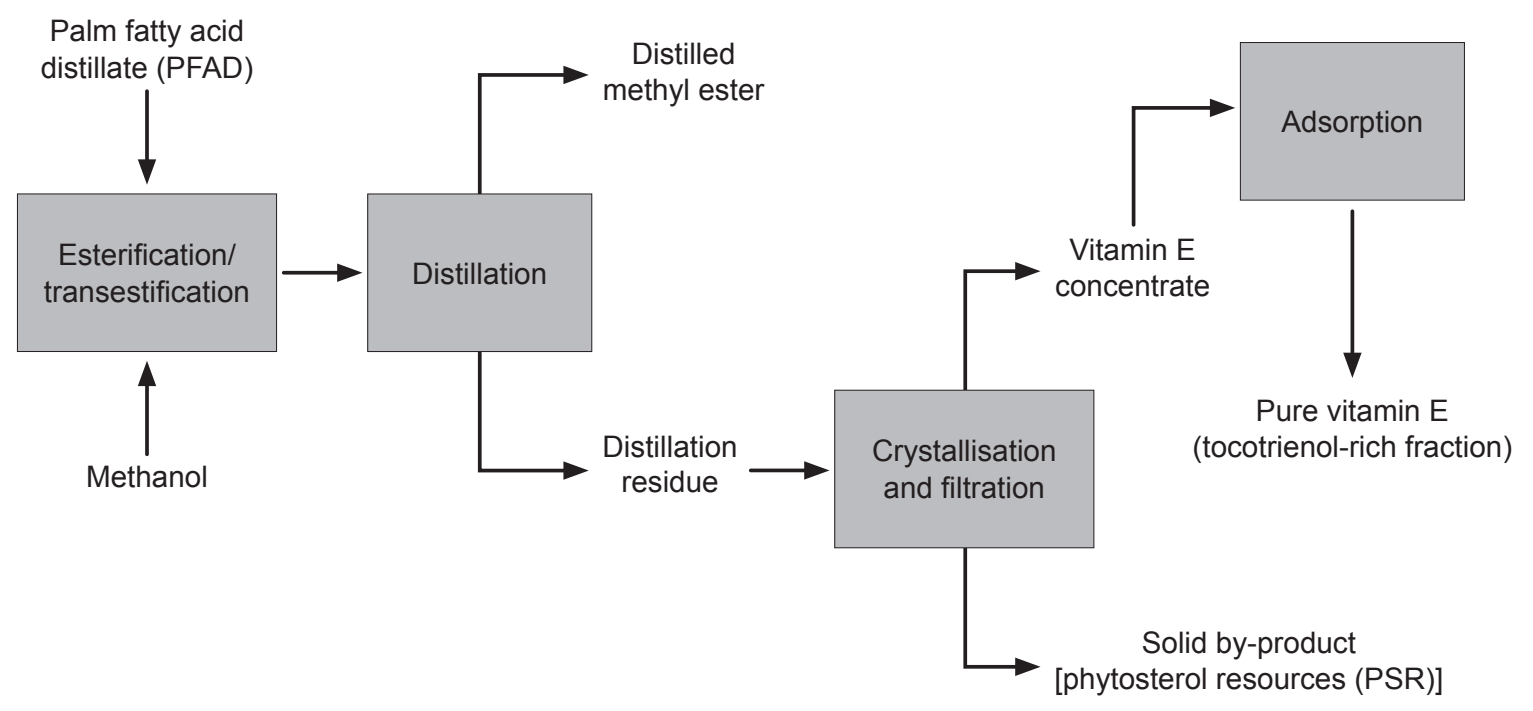

Figure 1. Extraction of vitamin E from palm fatty acid distillate (PFAD).

\section{Extraction of Phytosterols in Laboratory Scale}

A sample of $5 \mathrm{~g}$ PSR was mixed with $50 \mathrm{ml}$ of ethanol and $2.5 \mathrm{~g}$ of potassium hydroxide $(\mathrm{KOH})$, and then subjected to saponification reaction in $250 \mathrm{ml}$ round bottom flask equipped with reflux condenser. The reaction was conducted at the ethanol reflux temperature for $1 \mathrm{hr}$. The reacted mixture was then extracted five times with hexane until a colourless organic layer was obtained. The extracted organic layer was then washed with distilled water until the neutral $\mathrm{pH}$ was obtained. Excess solvent was evaporated and the sample was then mixed with various solvents namely hexane, ethanol, acetone and methanol before being subjected to purification stage. A $1 \mathrm{~g}$ of extracted sample phytosterols-rich fraction (PSRF) added with $10 \mathrm{ml}$ of solvent are heated to $60^{\circ} \mathrm{C}$ and then crystallised in deep freezer at temperature of $-5^{\circ} \mathrm{C}$ for $20 \mathrm{hr}$. The formed crystal was filtered and dried in oven. The final product was expected in a form of pure phytosterols mixture.

\section{Extraction of Phytosterols in Mini-pilot Scale Multistage Extraction Processes}

Extraction of phytosterols mixture. All the PSR samples were subjected to solid-liquid extraction (SLE) process using an overflow method with two different temperatures, $35^{\circ} \mathrm{C}$ and $50^{\circ} \mathrm{C}$. The SLE unit $\left(\right.$ SOLTEQ $\left.^{\circledR}\right)$ was equipped with a 20 -litre solvent pot with reboiler, distillation column, distillate condenser, extraction vessel and solvent collection vessel.

About $200 \mathrm{~g}$ of extracted product was subjected to saponification reaction for the recovery of unsaponifiable material (USM). The extract was then mixed with $100 \mathrm{~g} \mathrm{KOH}$ and ethanol (10 x sample weight), refluxed at $80^{\circ} \mathrm{C}$ to $90^{\circ} \mathrm{C}$ for $1 \mathrm{hr}$ to $4 \mathrm{hr}$. The reaction was conducted in a 10-litre multipurpose glass reactor equipped with a condenser, which was purchased from Buchiglasuster, Switzerland.

The reaction mixture was then subjected to liquid-liquid extraction (LLE) by mixing the reaction mixture with hexane and water at the ratio of 10:10:1 (hexane:water:sample) in order to extract the USM. The USM extracts or known as PSRF was collected in the light phase together with hexane, leaving the water-soluble compound in the heavy phase. The process was repeated for five cycles. The LLE process was conducted in a DN50 $1500 \mathrm{~mm}$ borosilicate column (25 litres capacity), manufactured by SOLTEQ ${ }^{\circledR}$, Malaysia.

Purification of phytosterols mixture. The PSRF extract was subsequently subjected to crystallisation process in a 5 litre crystallisation vessel equipped with vacuum filtration (Buchiglasuster, Switzerland) in order to further purify the phytosterols present in PSR samples. Different types of solvents (hexane, ethanol, methanol and acetone) were mixed with the PSRF with solvent to PSRF ratio (volume to weight) of 10:1. Then, the mixture was heated at $60^{\circ} \mathrm{C}$ for $1 \mathrm{hr}$ and cooled down to $-5^{\circ} \mathrm{C}$ for $19 \mathrm{hr}$. Finally, the mixture was filtered under vacuum condition, while the temperature was maintained at $-5^{\circ} \mathrm{C}$ during filtration. The solid and filtrate were analysed for total sterols content and quantified for product yield and recovery. The multistage extraction processes flow is illustrated in Figure 2. 


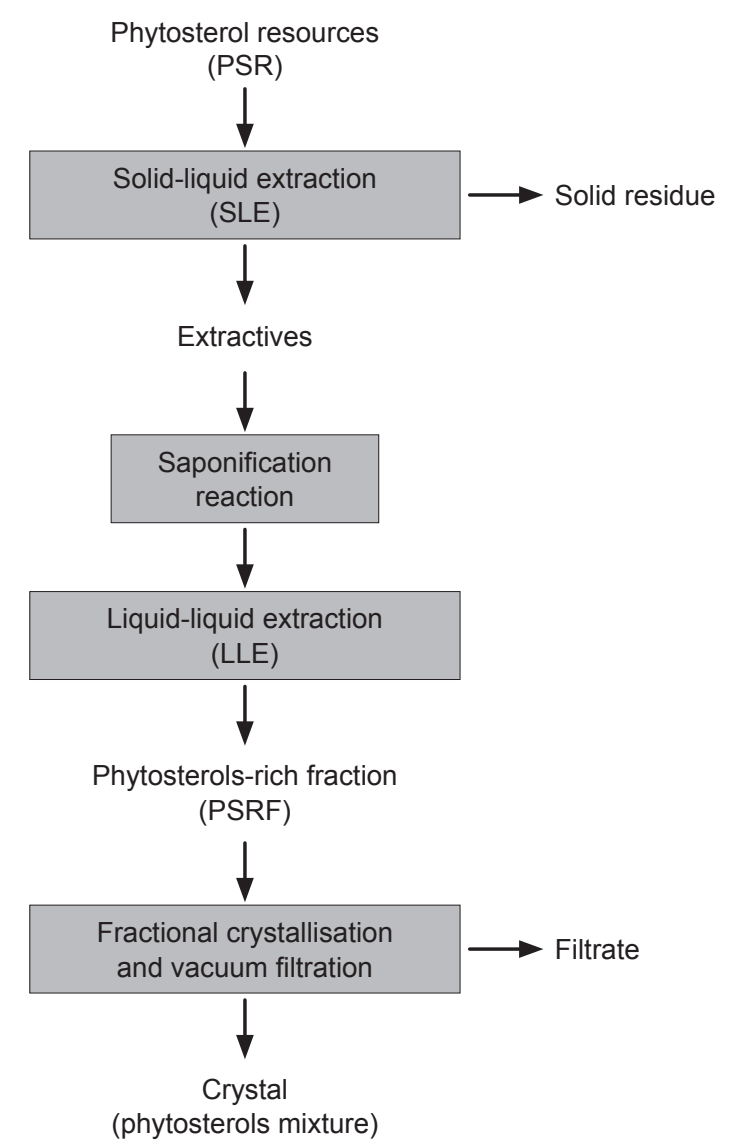

Figure 2. Multistage extraction processes of phytosterols mixture from the phytosterols resources (PSR).

\section{Analysis of Phytonutrients}

Samples preparation. All samples (except for PSRF and phytosterols mixture) were pre-treated via saponification prior to the analysis of sterols based on MPOB Test Method (MPOB, 2004). Samples weighing $5.0 \mathrm{~g}$ were mixed with $2.5 \mathrm{~g} 10 \%$ (w/v) $\mathrm{KOH}$ in an ethanolic solution and then refluxed for $1 \mathrm{hr}$ at temperature between $70^{\circ} \mathrm{C}$ to $80^{\circ} \mathrm{C}$. Then, hexane was used to extract the USM from the saponified mixture and the extracts were washed using distilled water until the neutral $\mathrm{pH}$ was obtained. The remaining moisture was removed using sodium sulphate $\left(\mathrm{NaSO}_{4}\right)$ and hexane was then removed using rotary evaporator. The USM was weighed to quantify the recovery yield as in Equation (1).

$$
\begin{gathered}
\text { Yield } \\
\text { of USM } \\
\text { recovery }
\end{gathered}=\frac{\begin{array}{c}
\text { Weight of PSR - Weight } \\
\text { of dried USM }
\end{array}}{\text { Weight of PSR }} \times 100 \quad \text { Equation (1) }
$$

Phytosterols, squalene and vitamin E determination using gas chromatography (GC) analyser. The samples were dissolved and diluted in 100\% n-hexane to an appropriate concentration. High purity samples such as PSRF and phytosterols mixture are directly dissolved in warm n-hexane without undergoing any pre-treatment. All the diluted sample were analysed using GC Autosystem XL, Perkin Elmer as a platform for the sterols separation equipped with flame ionisation detector (FID) for peak detection. The samples were separated in the capillary column purchased from Supelco SAC ${ }^{\mathrm{TM}}-5$ (Sigma) with the length of $30 \mathrm{~m}$ and internal diameter of $0.25 \mathrm{~mm}$, bonded with a $0.25 \mu \mathrm{m}$ film of $5 \%$ phenyl $/ 95 \%$ dimethylpolysiloxane in the presence of helium gas as mobile phase. The initial oven temperature, maximum oven temperature and detector temperature were set at $270^{\circ} \mathrm{C}, 320^{\circ} \mathrm{C}$ and $270^{\circ} \mathrm{C}$, respectively. Identification of compounds was achieved by comparing their retention times in GC spectra with those of standards (Table 1). For quantitative analysis, calibration curves were prepared by analysing different concentrations of squalene, vitamin $\mathrm{E}$ and sterol standards and by representing peak area versus concentration.

TABLE 1. RETENTION TIME FOR SQUALENE, VITAMIN E AND STEROLS DURING GAS CHROMATOGRAPHY-

\begin{tabular}{|c|c|}
\hline Components & Retention time (min) \\
\hline Squalene & 5.20 \\
\hline $\begin{array}{l}\text { Vitamin E } \\
\alpha \text {-tocopherol } \\
\alpha \text {-tocotrienol } \\
\gamma \text {-tocotrienol } \\
\delta \text {-tocotrienol }\end{array}$ & $\begin{array}{r}7.60 \\
8.60 \\
9.30 \\
10.92\end{array}$ \\
\hline $\begin{array}{l}\text { Sterols } \\
\text { Cholesterol } \\
\text { Campestrols } \\
\text { Stigmasterols } \\
\beta \text {-sitosterols }\end{array}$ & $\begin{array}{r}8.80 \\
10.80 \\
11.40 \\
12.70\end{array}$ \\
\hline
\end{tabular}
FLAME IONISATION DETECTOR (GC-FID) ANALYSIS

Fourier transform infrared (FTIR) analysis. The infrared spectrum of sterols samples was recorded using Perkin-Elmer Spectrum One FTIR Spectrometer with wavelength in the range of $4000-650 \mathrm{~cm}^{-1}$. The spectrums were compared with the individual sterols standard.

Nuclear magnetic resonance (NMR) analysis. Samples were dissolved in $200 \mu$ l deuterated chloroform, shaken and placed in a $5 \mathrm{~mm}$ NMR capillary tube. The ${ }^{1} \mathrm{H}$ and ${ }^{13} \mathrm{C}$ experiments were performed using $600 \mathrm{MHz}$ JEOL Spectrometer for compound identification [adapted from Teh et al. (2017)].

\section{RESULTS AND DISCUSSIONS}

\section{Phytosterols Composition in Palm Oil and its By- products}

Various oil palm by-products were analysed for their phytosterols content, The composition of extracted USM and total phytosterols content 
in palm oil and its by-products are as tabulated in Table 2. Results showed that OPEFB residual oil and CPO have low USM content of $0.82 \%-0.83 \%$. These two samples composed of only $5.48 \%-6.19 \%$ of phytosterols in USM, with only 450-500 ppm of total phytosterols composition in these PSR. Another component of USM might be carotene, which makes the oil reddish in colour (Rusnani et al., 2012; Md Yunos et al., 2015). Other than these two samples, the phytosterols content in SPO was recorded at 800-1100 ppm, followed by PPFO with 1700-4100 ppm phytosterols. USM recovery percentage of both samples were less than $2 \%$. It was observed that the phytosterols composition in this SPO (800-1000 ppm) was higher than that in the slurry obtained from the heavy phase of CPO clarification tank (508.7 ppm). This might be due to the dilution of the sludge with water from CPO clarification process (Teh et al., 2017). Meanwhile, the SPO composed of only oil recovered and concentrated from that particular sludge. Besides, it was reported that most of USM in POME composed from carotene, squalene and vitamin E (Sangkharak et al., 2016; Teh et al., 2017). As expected, the highest phytosterols content of 20 300-141 000 ppm was found in solid by-product from vitamin E extraction process. This PSR sample contained $3.82 \%-15.15 \%$ USM. The phytosterols content in this PSR sample is relatively higher than palm phytonutrient concentrate produced from palm methyl ester as reported by Chandrasekaram (2009). The higher value of phytosterols in this sample was due to the fact that most of the esters and glycerides were primarily removed during the distillation process for vitamin $\mathrm{E}$ extraction. The remaining esters, squalene and vitamin $\mathrm{E}$ were also extracted in liquid fraction during the crystallisation and filtration process. This sample also had the highest total phytosterols content in USM of more than $50 \%$, which allowed simpler purification step to obtain phytosterols as compared to other PSR samples. Besides high total phytosterols content, relatively low fatty acids content reduces the requirement of the equipment size towards the downstream stages of the extraction processes (Fernandes and Cabral, 2007).

\section{Extraction of Phytosterols Mixture from PSR}

Process for extraction of vitamin E from PFAD produced $1.50 \%(\mathrm{w} / \mathrm{w})$ solid by-product. This solid by-product PSR composed of up to $15.15 \%$ USM that mostly consisted of phytosterols. This contributed to high content of phytosterols in the PSR samples amounting to $14.10 \%$. The extraction of phytosterols from this PSR was conducted through SLE using $100 \%$ n-hexane at $35^{\circ} \mathrm{C}$ and $50^{\circ} \mathrm{C}$. Temperature of $35^{\circ} \mathrm{C}$ was selected to represent the extraction at constant room temperature adapted from the maceration method (Azwanida, 2015). Warm solvent at $50^{\circ} \mathrm{C}$ enhanced the extraction of phytosterols. However, the temperature for extraction must be below hexane boiling point in order to avoid solvent evaporation. Solvent extraction at $35^{\circ} \mathrm{C}$ yielded $47 \%$ extractives (Table 3 ). The yield was increased to more than $90 \%$ when extraction temperature was set at $50^{\circ} \mathrm{C}$. The extractive yield was lower but the extract contained higher USM, which consequently increased the total sterols content in the extract. Solubility of fatty acids and methyl ester in hexane is lesser at lower temperature (Calvo et al., 2009). Therefore, solvent temperature at $35^{\circ} \mathrm{C}$ is preferred for extraction of phytosterols in order to minimise the carry over of fatty acids and methyl ester in the extract. Different solvent temperatures will give different products and recovery yields due to the differences in component solubility in hexane.

After the SLE process, saponification was carried out to convert all sterol esters into free sterol and all glycerides into water-soluble fatty acid soap. The reaction was conducted in laboratory scale by varying the duration of reaction time between $1 \mathrm{hr}$ to $4 \mathrm{hr}$ in order to determine the highest USM recovery. It was found that as the reaction time increased, the recovery of USM reduced from $43.70 \%$ at $1 \mathrm{hr}$ to $23.60 \%$ at $4 \mathrm{hr}$ (Figure 3). The longer reaction time has continuously exposed samples to heat and it may have destroyed some phytonutrients in USM such as sterols and squalene (Lau et al., 2005).

TABLE 2. PHYTOSTEROLS CONTENT IN VARIOUS PALM OIL AND ITS BY-PRODUCTS

\begin{tabular}{|c|c|c|c|}
\hline Phytosterols resources & $\begin{array}{l}\text { Unsaponifiable } \\
\text { matter recovery } \\
\qquad(\%)\end{array}$ & $\begin{array}{l}\text { Phytosterols composition in } \\
\text { unsaponifiable matter form } \\
\qquad(\%)\end{array}$ & $\begin{array}{l}\text { Phytosterols } \\
\text { composition } \\
\text { (ppm) }\end{array}$ \\
\hline Crude palm oil* & 0.83 & 6.19 & 500 \\
\hline Palm fatty acid distillate & $1.86-2.87$ & $2.39-15.33$ & $600-4200$ \\
\hline Palm pressed fibre oil & $0.96-1.58$ & $17.99-25.93$ & $1700-4100$ \\
\hline Oil palm empty fruit bunch residual oil ${ }^{*}$ & 0.82 & 5.48 & 450 \\
\hline Sludge palm oil & $1.15-1.17$ & $7.16-9.04$ & $800-1100$ \\
\hline Solid by-product of vitamin E extraction process & $3.82-15.15$ & $50.35-93.12$ & $20300-141000$ \\
\hline
\end{tabular}

Note: *Analysis of one sample. 
TABLE 3. TOTAL STEROLS AND ITS COMPOSITION DURING SOLID-LIQUID EXTRACTION

\begin{tabular}{|c|c|c|c|c|c|c|}
\hline \multirow{2}{*}{$\begin{array}{l}\text { Solvent temperatures } \\
\text { Extracted components }\end{array}$} & \multicolumn{3}{|c|}{$35^{\circ} \mathrm{C}$} & \multicolumn{3}{|c|}{$50^{\circ} \mathrm{C}$} \\
\hline & PSR & Extractives & Solid residue & PSR & Extractives & Solid residue \\
\hline $\operatorname{USM}(\%)$ & 19.45 & 41.27 & 0.07 & 16.10 & 16.97 & 6.82 \\
\hline Total sterols in samples $(\%)$ & 13.75 & 25.35 & 0.01 & 8.55 & 8.61 & 5.82 \\
\hline \multicolumn{7}{|c|}{ Sterols composition in USM $(\%)^{*}$} \\
\hline Cholesterol & 1.39 & 4.12 & 4.12 & 1.42 & 1.58 & 1.43 \\
\hline Campesterol & 22.66 & 23.53 & 20.29 & 22.72 & 23.26 & 23.73 \\
\hline Stigmasterol & 14.96 & 16.60 & 21.32 & 15.55 & 15.67 & 19.33 \\
\hline$\beta$-sitosterol & 60.99 & 55.75 & 54.26 & 60.32 & 59.49 & 55.51 \\
\hline Yield $(\%)$ & - & 47 & 53 & - & 91.5 & 8.5 \\
\hline Sterols recovery $(\%)$ & - & 99.95 & - & - & 94.09 & - \\
\hline
\end{tabular}

Note: PSR - phytosterol resources; USM - unsaponifiable matter.

${ }^{*}$ Normalised to $100 \%$.

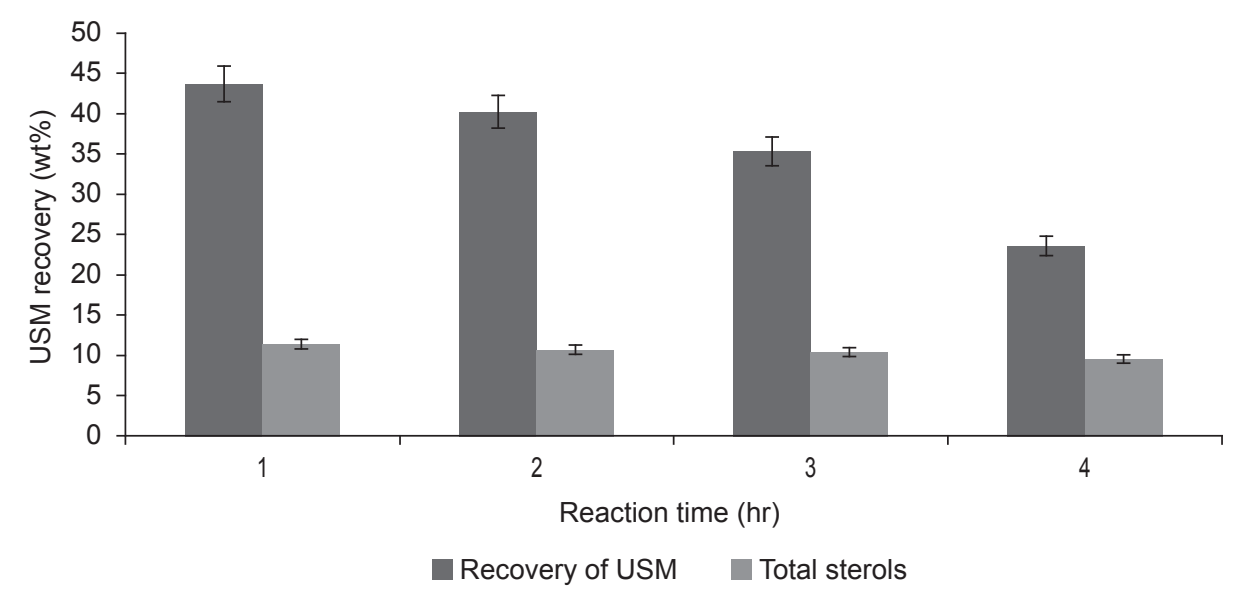

Figure 3. Effect of reaction time on the recovery of unsaponifiable matter (USM) from solid residue of vitamin E extraction.

As such, the mini-pilot test was conducted using optimised saponification reaction time of 1 $\mathrm{hr}$. The amount of solvent used in mini-pilot liquidliquid extraction was fixed at a ratio of 10:1 in order to maximise the extraction of phytosterols. The USM recovery in mini-pilot test was in the range of $14.32 \%-19.95 \%$ after five runs. The average sterols content was $47.64 \% \pm 4.78 \%$. Apart from phytosterols, the USM also contained squalene and traces of unreacted glycerides. Sterols and squalene have great differences in melting point and hence, solvent-assisted crystallisation process was used to isolate the phytosterols from the squalene and other USM mixtures. The separation of free phytosterols and tocopherols is usually performed through fractional crystallisation as free phytosterols tend to precipitate at a low temperature (Moreira and Baltanás, 2004).

\section{Purification of Phytosterols Mixture}

Phytosterols mixture extract was further purified using crystallisation. Crystallisation is one of the best and cheapest methods available for the purification of solids from impure solutions. There are several types of solvents and solvent mixtures suitable for the crystallisation procedure. However, a simple purification process should use only one solvent instead of mixed solvents for recovery and recycling purposes. In this study, four types of solvents have been tested in laboratory scale crystallisation; they were ethanol, methanol, acetone and hexane (Table 4). From this experiment, crystallisation of USM with hexane gave the highest crystal yield of $62 \%$ with pure phytosterols $(100 \%$ purity), followed by ethanol and then acetone. The lowest crystal yield obtained was when methanol was used as solvent, producing 25\% crystal yield with phytosterols content of $48.25 \%$. Other solvents such as benzene, toluene and cyclohexane may give higher sterols purity, but with lower yield and highly toxic (Yan et al., 2011). Thus, these solvents are not desirable for crystallisation of phytosterols.

The crystallisation process was further tested at mini-plant scale, using hexane and ethanol as solvents. The yield of crystal and filtrate are tabulated in Table 5. The crystal yield and sterol content for mini-pilot scale were lower than that 
of laboratory scale crystallisation. This was due to higher phytosterols loss in the filtrate. The purity of phytosterols obtained was also lower than that of laboratory scale extraction. However, the crude phytosterols purity was maintained at more than $80 \%$. This was due to the presence of other impurities such as unreacted glycerides that have close melting point as sterols.

\section{Characterisation of Phytosterols Mixture}

Phytosterols mixture after the purification process was a waxy solid and white in colour. Table 6 shows the individual sterols composition in PFAD, phytosterols mixture (phytosterols-mix) extracted in laboratory and mini-pilot scale in comparison with commercial vegetable oil sterols. It was found that $\beta$-sitosterol content in palm-based sterols is higher than commercial sterols, while stigmasterols content is lower. The $\beta$-sitosterol has advantages to treat men's health problems such as increased urinary flow rates, decreasing the amount of urine left in the bladder after urinating and improving the overall quality of life (Wilt et al., 1999).

Apart from GC analysis, the extracted phytosterols were further analysed using FTIR and NMR to confirm their characteristics. FTIR spectrum (Figure 4) showed the absorption bands at $3345.68 \mathrm{~cm}^{-1}(\mathrm{OH}), 2920.02 \mathrm{~cm}^{-1}\left(\mathrm{CH}_{2}\right)$ and $2850.54 \mathrm{~cm}^{-1}(\mathrm{CH})$. The absorption at $1641.6 \mathrm{~cm}^{-1}$ for the olefinic bond in stigmasterol was also sighted.
However, the band was weakly absorbed due to the $\mathrm{C}=\mathrm{C}$ stretching. A bending frequency of cyclic $\left(\mathrm{CH}_{2}\right)$ and $-\mathrm{CH}_{2}\left(\mathrm{CH}_{3}\right) \gamma$ were observed at $1461.81 \mathrm{~cm}^{-1}$ and $1377.95 \mathrm{~cm}^{-1}$ respectively. The absorption frequency at $1051.89 \mathrm{~cm}^{-1}$ and $958.79 \mathrm{~cm}^{-1}$ were that of trisubstituted olefin, which were usually referred to as $\beta$-sitosterol and stigmasterol (Jamaluddin et al., 1994).

The ${ }^{13} \mathrm{C}$ NMR spectrum (Figure 5) shows that the presence of the compound in phytosterols mixture is in a form of steroid skeleton due to similar chemical shift obtained as compared in the literature (Jain and Bari, 2010; Jamaluddin et al., 1994). The main difference between the three main sterols is the presence of double bond at C22 $=$ C23 in stigmasterols with a chemical shift at 138.404 and $129.247 \mathrm{ppm}$, while $\beta$-sitosterols and campesterol both have a chemical shift at 34.020 and $26.150 \mathrm{ppm}$ corresponding to C22-C23 single bond. The ${ }^{13} \mathrm{C}$ NMR spectrum for campesterol and $\beta$-sitosterols were identical, thus, the presence of those two compounds were confirmed.

Based on mini-pilot plant trial, it was estimated that one tonne of PFAD will produce $15 \mathrm{~kg}$ byproduct of PSR during the vitamin E extraction process. After multistage extraction process, 1.08 $\mathrm{kg}$ phytosterols mixture with average purity of $87.23 \%$ was obtained with overall sterols recovery from the PSR of about $84 \%$. Overall mass balance on the multistage production of phytosterols mixture from PFAD is given in Figure 6.

TABLE 4. PURIFICATION OF PHYTOSTEROLS-RICH FRACTION (PSRF) THROUGH CRYSTALLISATION WITH DIFFERENT TYPES OF SOLVENTS IN LABORATORY SCALE

\begin{tabular}{|c|c|c|c|c|c|c|c|}
\hline \multirow{2}{*}{ Solvent type } & \multirow{2}{*}{ Samples } & \multicolumn{4}{|c|}{ Sterols composition $(\%)$} & \multirow{2}{*}{$\begin{array}{c}\text { Total sterols } \\
(\%)\end{array}$} & \multirow{2}{*}{ Yield $(\%)$} \\
\hline & & Cholesterol & Campesterol & Stigmasterol & $\beta$-Sitoterol & & \\
\hline \multirow[t]{2}{*}{ Ethanol } & Crystal & 7.02 & 18.58 & 16.37 & 58.03 & 93.92 & 43 \\
\hline & Filtrate & 0.00 & 24.32 & 0.00 & 75.68 & 22.24 & \\
\hline \multirow[t]{2}{*}{ Methanol } & Crystal & 10.20 & 3.42 & 28.81 & 57.57 & 48.25 & 25 \\
\hline & Filtrate & 12.57 & 23.29 & 0.00 & 64.14 & 11.41 & \\
\hline \multirow[t]{2}{*}{ Acetone } & Crystal & 5.39 & 17.32 & 18.31 & 58.98 & 100.00 & 32 \\
\hline & Filtrate & 11.12 & 29.06 & 19.62 & 40.20 & 22.19 & \\
\hline \multirow[t]{2}{*}{ Hexane } & Crystal & 4.87 & 19.18 & 17.16 & 58.78 & 100.00 & 62 \\
\hline & Filtrate & 8.47 & 20.43 & 0.00 & 71.11 & 32.97 & \\
\hline
\end{tabular}

TABLE 5. PURIFICATION OF PHYTOSTEROLS-RICH FRACTION (PSRF) THROUGH CRYSTALLISATION IN MINI-PILOT SCALE

\begin{tabular}{|c|c|c|c|c|c|c|}
\hline \multirow{2}{*}{ Solvent type } & \multirow{2}{*}{ Samples } & \multicolumn{4}{|c|}{ Phytonutrient composition (\%) } & \multirow{2}{*}{$\begin{array}{c}\text { Yield of phytosterols } \\
\text { mixture }(\%)\end{array}$} \\
\hline & & Sterol & Squalene & Vitamin E & Others & \\
\hline \multirow[t]{2}{*}{ Ethanol } & Crystal & 84.47 & 0.21 & N.D & 18.32 & 37 \\
\hline & Filtrate & 68.40 & 20.97 & N.D & 10.63 & \\
\hline \multirow[t]{2}{*}{ Hexane } & Crystal & 87.23 & 0.66 & N.D & 12.11 & 47 \\
\hline & Filtrate & 59.62 & 13.40 & N.D & 26.98 & \\
\hline
\end{tabular}

Note: N.D - not detected. 
TABLE 6. INDIVIDUAL STEROLS COMPOSITION IN PALM FATTY ACID DISTILLATE (PFAD), PHYTOSTEROLS MIXTURE FROM PFAD AND COMMERCIAL STEROLS

\begin{tabular}{lcccc}
\hline \multirow{2}{*}{ Sample/ Material } & \multicolumn{3}{c}{ Individual sterols compositions (\%) } \\
\cline { 2 - 5 } & Cholesterol & Campesterol & \multicolumn{1}{c}{ Stigmasterol } & $\beta$-Sitosterol \\
\hline PFAD & $3-9$ & $23-25$ & $13-14$ & $53-60$ \\
Phytosterol-mix (laboratory) & $1-5$ & $19-22$ & $17-20$ & $57-59$ \\
Phytosterol-mix (mini-pilot plant) & $<2$ & $20-22$ & $13-20$ & $59-63$ \\
Commercial sterol $^{*}$ & $<3^{* *}$ & $20-28$ & $16-23$ & $40-58$ \\
\hline
\end{tabular}

Note: *Corowise ${ }^{\mathrm{TM}}$ sterols. ** Other minor sterols.

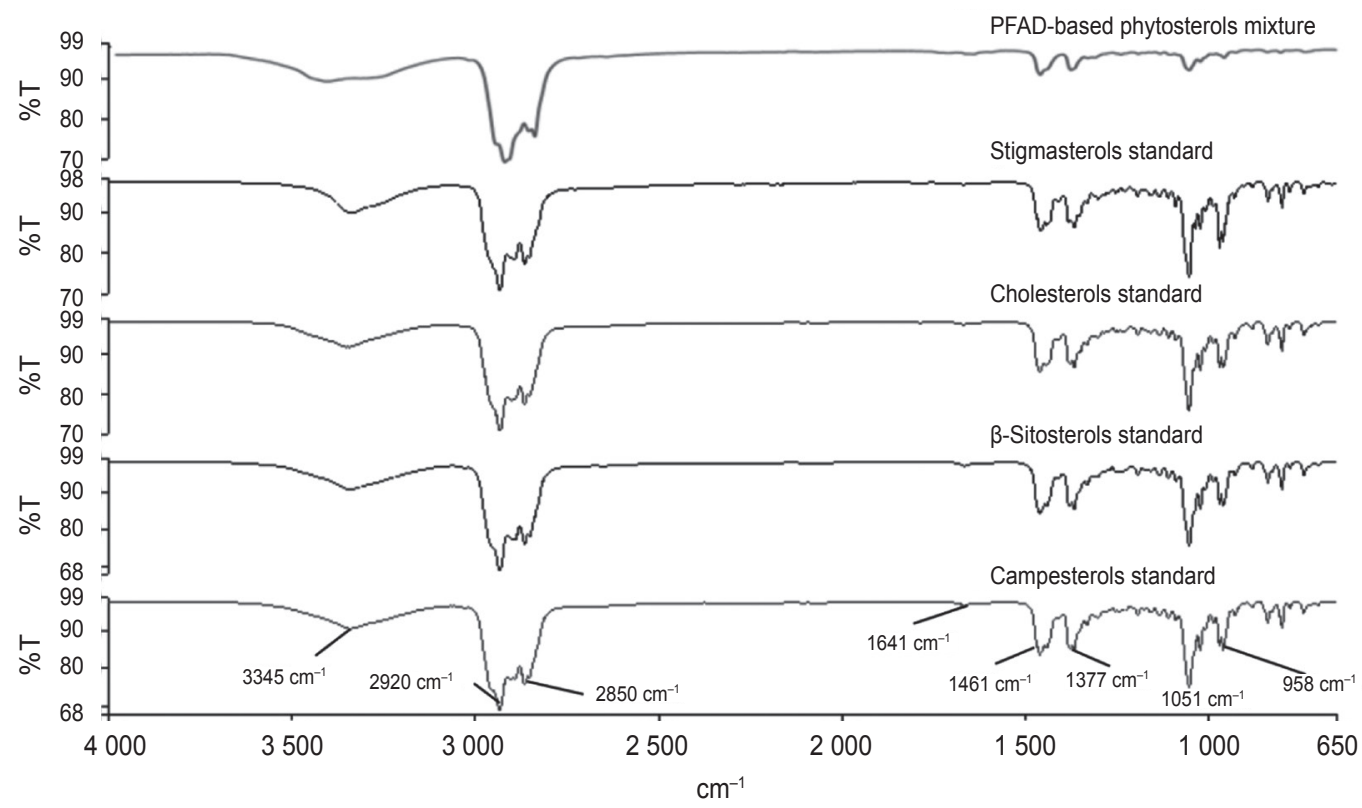

Figure 4. IR spectrum of stigmasterols, $\beta$-sitosterols, campesterols and cholesterol standard and phytosterols mixture extracted from palm fatty acid distillate (PFAD).

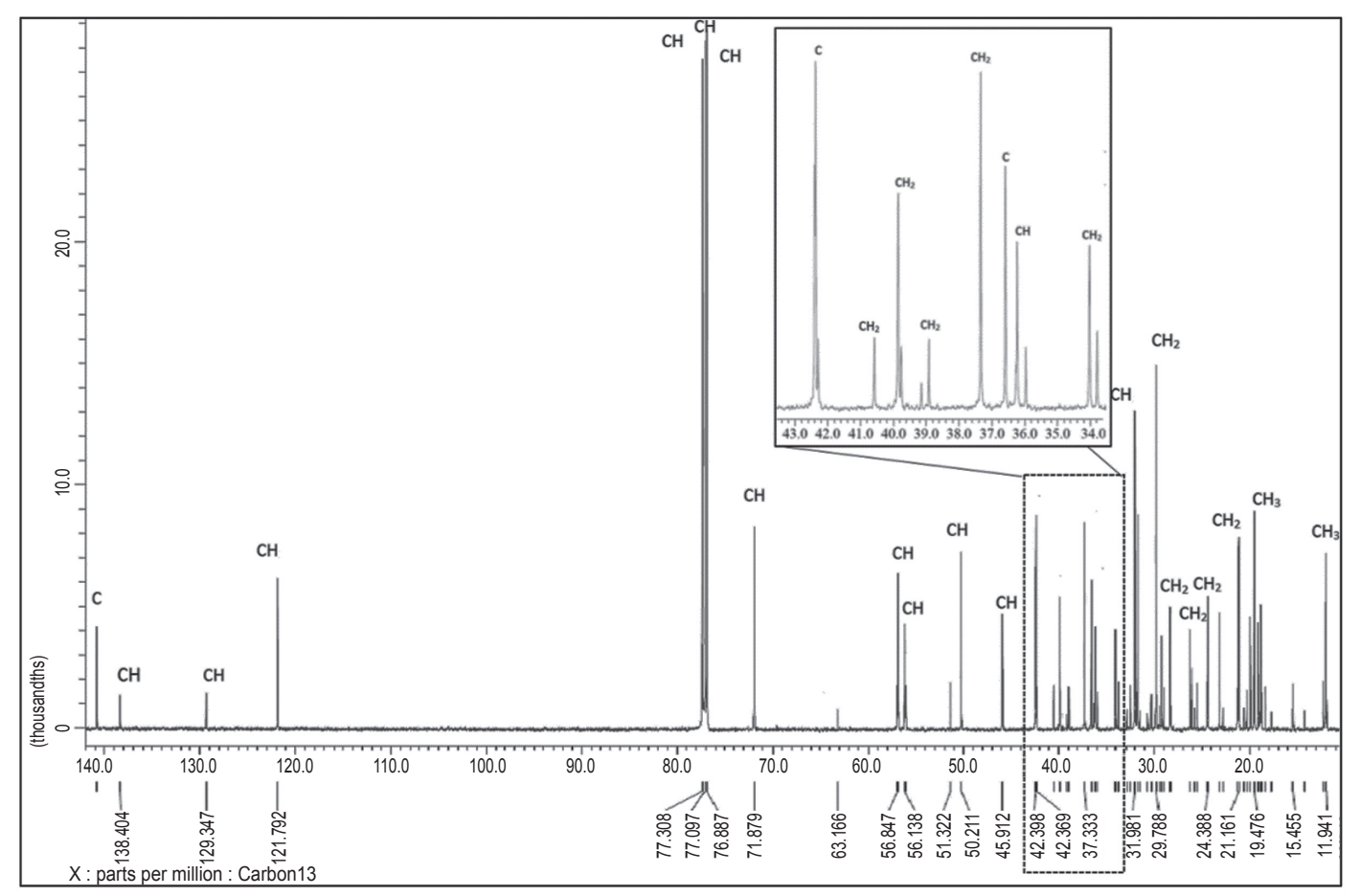

Figure 5. The ${ }^{13} \mathrm{C}$ NMR spectrum of phytosterols mixture extracted from palm fatty acid distillate (PFAD). 


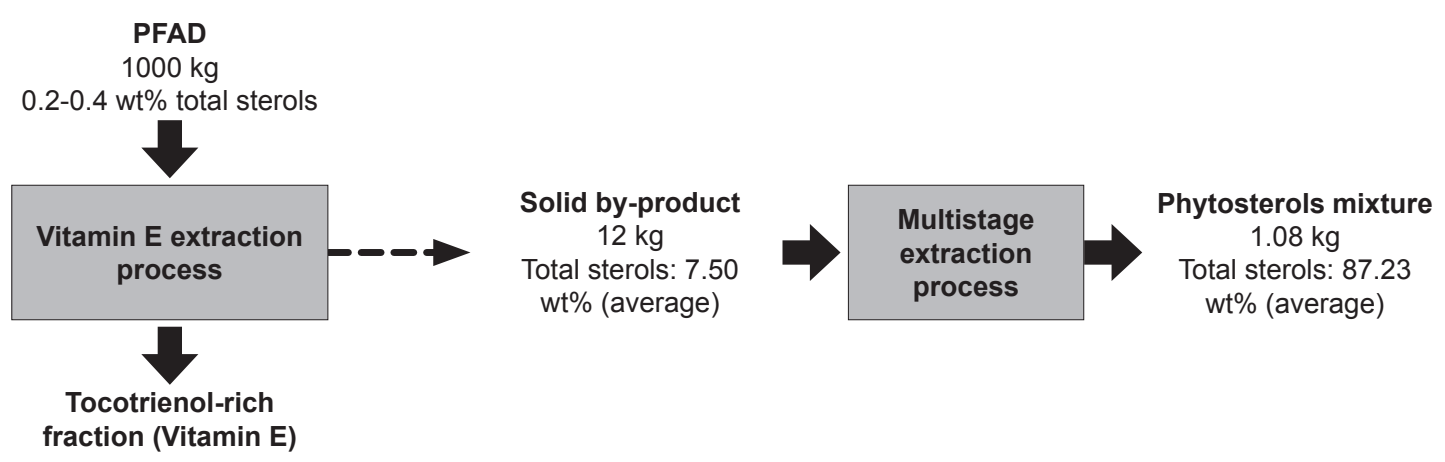

Figure 6. The overall mass balance on the multistage production of phytosterols mixture from palm fatty acid distillate (PFAD).

\section{CONCLUSION}

Extraction and purification of phytosterols from solid residue obtained after vitamin E extraction from PFAD have been successfully conducted using multistage extraction processes in laboratory scale and mini-pilot scale. Technically, the multistage extraction and purification methods in mini-pilot scale which comprised of SLE, saponification reaction, LLE, crystallisation and filtration, were capable to produce phytosterols mixture with purity of up to $94 \%(\mathrm{w} / \mathrm{w})$ with individual sterols compositions of $\beta$-sitosterol ( $21 \%$-22\%), campesterol $(13 \%-20 \%)$ and stigmasterol $(59 \%-64 \%)$. The overall recovery for sterol from the PSR was $84 \%$. FTIR, NMR and GC analysis confirmed the presence of phytosterols in the extract. This extraction process is technically feasible to extract and produce crude phytosterols from a PFAD by-product and the extraction of this minor component will adds value to the oil palm industry.

\section{ACKNOWLEDGEMENT}

The authors wish to thank the Director-General and Director of Engineering and Processing Division of $\mathrm{MPOB}$ for their encouragement and permission to publish this article. Thanks are extended to $\mathrm{Dr} \mathrm{Ab}$ Gapor Md Top and NUTRADEC staff for providing excellent technical assistance.

\section{REFERENCES}

Ab Gapor, M T (2010). Production and utilization of palm fatty acid distillate (PFAD). Lipid Technol., 22: 11-13.

Ab Gapor, M T; Leong, W L; Augustine, O S H; Kawada, T; Watanabe, H and Tsuchiya, N (1993). Production of high concentration tocopherols and tocotrienols from palm oil by-products. US patent No. 5190618.
Akgun, N A (2011). Separation of squalene from olive oil deodorizer distillate using supercritical fluids. Eur. J. Lipid Sci. Technol., 113: 1558-1565.

Awad, A B and Fink, C S (2000). Phytosterols as anticancer dietary components: Evidence and mechanism of action. J. Nutr., 130: 2127-2130.

Azwanida, N N (2015). A review on the extraction methods use in medicinal plants, principle, strength and limitation. Med. Aromat. Plants, 4: 196.

Calvo, B; Collado, I and Cepeda, E A (2009). Solubilities of palmitic acid in pure solvents and its mixtures. J. Chem. Eng. Data, 54: 64-68.

Chandrasekaram, K (2009). Analysis of Phytonutrients from Palm Concentrates by High Performance Liquid Analysis of Phytonutrients from Palm Concentrates by High Performance Liquid. M.Sc thesis. Universiti Malaya.

Choo, Y M; Lau, H L N; Ma, A N and Yusof, B (2005a). Extraction of palm vitamin $\mathrm{E}$, phytosterols and squalene from palm oil. US patent No. 20050250953A1.

Devaraj, S and Jialal, I (2006). The role of dietary supplementation with plant sterols and stanols in the prevention of cardiovascular disease. Nutr. Rev., 64: 348-354.

Fernandes, P and Cabral, J M S (2007). Phytosterols: Applications and recovery methods. Bioresour. Technol., 98: 2335-2350.

Jain, P S and Bari, S B (2010). Isolation of lupeol, stigmasterol and campesterol from petroleum ether extract of woody stem of Wrightia tinctoria. Asian J. Plant., 9: 163-167.

Jamaluddin, F; Mohamed, S and Lajis, N (1994). Hypoglycaemic effect of Paria speciosa seeds due to the synergistic action of $\beta$-sitosterol and stigmasterol. Food Chem., 49: 339-345. 
Jones, P J H; Ntanios, F Y; Raeini-sarjaz, $\mathrm{M}$ and Vanstone, C A (1999). Cholesterol-lowering efficacy of a sitostanol-containing phytosterol mixture with a prudent diet in hyperlipidemic men. Am. J. Clin. Nutr., 69: 1144-1150.

Kowalski, R E (2017). Plant sterols: A natural way to lower cholesterol. http: / / www.corowise.com/ articles/07 plantsterols.html., accessed on 14 December 2017.

Kushairi, A; Loh, S K; Elina, H; Meilina, O; Mohd Noor Izuddin, Z B; Razmah, G; Sundram, S and Parveez, G K A (2018). Oil palm economic performance in Malaysia and R\&D progress in 2017. J. Oil Palm Res. Vol. 30(2): 163-195.

Lau, H L N; Puah, C W; Choo, Y M; Ma, A N and Chuah, C H (2005). Simultaneous quantification of free fatty acids, free sterols, squalene, and acylglycerol molecular species in palm oil by hightemperature gas chromatography - Flame ionization detection. Lipids, 40: 3-8.

Lau, H L N; Choo, Y M; Ma, A N and Chuah, C H (2008). Selective extraction of palm carotene and vitamin $\mathrm{E}$ from fresh palm-pressed mesocarp fiber (Elaeis guineensis) using supercritical $\mathrm{CO}_{2}$. J. Food Eng., 84: 289-296.

Massimo, L; Laura, D and Ginevra, L B (2019). Phytosterols and phytosterol oxides in Bronte's pistachio (Pistacia vera L.) and in processed pistachio products. Eur. Food Res. Technol., 246: 307-314.

Md Yunos, N; Samsu Baharudin, A; Md Yunos, K; Hafid, H; Busu, Z; Mokhtar, M and Md Som, A (2015). The physicochemical characteristics of residual oil and fibers from oil palm empty fruit bunches. BioResources, 10: 14-29.

Moreau, R A; Nyström, L; Whitaker, B D; WinklerMoser, J K; Baer, J; Gebauer, S K and Hicks, K B (2018). Phytosterols and their derivatives: Structural diversity, distribution, metabolism, analysis, and health-promoting uses. Prog. Lipid Res., 70: 35-61.

Moreira, E A and Baltana's, M A (2004). Recovery of phytosterols from sunflower oil deodorizer distillates. J. Amer. Oil Chem. Soc., 81: 161-167.

MPOB (2004). MPOB Test Methods. MPOB, Bangi. $395 \mathrm{pp}$.

$\mathrm{Ng}, \mathrm{M} \mathrm{H}$ and Choo, Y M (2013). Isolation and recovery of phytonutrients in palm by isocrated and isobaric flash chromatography. J. Oil Palm Res. Vol. 25: 165-169.

Noorshamsiana, A W; Astimar, A A; Iberahim, N I; Nor Faizah, J; Anis, M; Hamid, F A and Kamarudin, $H$ (2017). The quality of oil extracted from palm pressed fibre using aqueous enzymatic treatment. J. Oil Palm Res. Vol. 29(4): 588-593.

Norhidayah, S; Baharin, B S; Hamed, M and Zaidul, I S M (2012). Squalene recovery from palm fatty acid distillate using supercritical fluid extraction. Int. Food Res. J., 19: 1661-1667.

Phoon, K Y; Ng, H S; Zakaria, R; Yim, H S and Mokhtar, M N (2018). Enrichment of minor components from crude palm oil and palm-pressed mesocarp fibre oil via sequential adsorptiondesorption strategy. Ind. Crops Prod., 113: 187-195.

Rusnani, A M; Mohammad, A W and Choo, Y M (2012). Properties of residual palm pressed fibre oil. J. Oil Palm Res. Vol. 24: 1310-1317.

Sangkharak, K; Pichid, N and Yunu, T (2016). Separation of carotenes and vitamin e from palm oil mill effluent using silica from agricultural waste as an adsorbent. Walailak J. Sci. and Tech., 13: 939-947.

Sugihara, N; Kanda, A; Nakano, T; Nakamura, T; Igusa, H and Hara, S (2010). Novel fractionation method for squalene and phytosterols contained in the deodorization distillate of rice bran oil. J. Oleo. Sci., 59: 65-70.

Tasan, M; Bilgin, B; Gecgel, Ü and Demirci, A Ş (2006). Phytosterols as functional food ingredients chemical structures of phytosterols. J. Tekirdag Agric. Fac., 3: 153-159.

Teh, S S; Hock Ong, A S and Mah, S H (2017). Recovery and utilization of palm oil mill effluent source as value-added food products. J. Oleo Sci., 66: 1183-1191.

Wilt, T J; Ishani, A; MacDonald, R; Stark, G; Mulrow, C D and Lau, J (1999). Beta-sitosterols for benign prostatic hyperplasia. Cochrane Database of Systematic Reviews 1999 Issue 3. Art. No. CD001043. DOI: 10.1002/14651858.CD001043.

Yan, F; Yang, H, Wu, D; Huo, M and Li, X (2011). Recovery of phytosterols from waste residue of soybean oil deodorizer distillate. Soybean Applications and Technology (Ng, T ed.). p. 329-340.. 